\title{
Effect of protein provision via milk replacer or solid feed on protein metabolism in veal calves
}

\author{
H. Berends, ${ }^{* 1,2}$ J. J. G. C. van den Borne, ${ }^{*}$ B. A. Røjen, $\dagger^{3}$ W. H. Hendriks, ${ }^{*}$ and W. J. J. Gerrits* \\ ${ }^{*}$ Animal Nutrition Group, Wageningen University, PO Box 338, $6700 \mathrm{AH}$ Wageningen, the Netherlands \\ †Department of Animal Health and Bioscience, Aarhus University, DK-8830 Tjele, Denmark
}

\begin{abstract}
The current study evaluated the effects of protein provision to calves fed a combination of solid feed (SF) and milk replacer (MR) at equal total $\mathrm{N}$ intake on urea recycling and $\mathrm{N}$ retention. Nitrogen balance traits and $\left[{ }^{15} \mathrm{~N}_{2}\right]$ urea kinetics were measured in 30 calves ( $23 \mathrm{wk}$ of age, $180 \pm 3.7 \mathrm{~kg}$ of body weight), after being exposed to the following experimental treatments for $11 \mathrm{wk}$ : a low level of $\mathrm{SF}$ with a low $\mathrm{N}$ content (SF providing $12 \%$ of total $\mathrm{N}$ intake), a high level of SF with a low $\mathrm{N}$ content (SF providing $22 \%$ of total $\mathrm{N}$ intake), or a high level of SF with a high $\mathrm{N}$ content (SF providing $36 \%$ of total $\mathrm{N}$ intake). The SF mixture consisted of $50 \%$ concentrates, $25 \%$ corn silage, and $25 \%$ straw on a dry matter basis. Total $\mathrm{N}$ intake was equalized to $1.8 \mathrm{~g}$ of $\mathrm{N} \cdot \mathrm{kg}$ of $\mathrm{BW}^{-0.75} \cdot \mathrm{d}^{-1}$ by adjusting $\mathrm{N}$ intake via MR. All calves were housed individually on metabolic cages to allow for quantification of a $\mathrm{N}$ balance of calves for $5 \mathrm{~d}$, and for the assessment of urea recycling from $\left[{ }^{15} \mathrm{~N}_{2}\right]$ urea kinetics. Increasing low-N SF intake at equal total $\mathrm{N}$ intake resulted in a shift from urinary to fecal $\mathrm{N}$ excretion but did not affect protein retention (0.71 $\mathrm{g}$ of $\mathrm{N} \cdot \mathrm{kg}$ of $\left.\mathrm{BW}^{-0.75} \cdot \mathrm{d}^{-1}\right)$. Increasing low-N SF intake increased urea recycling but urea reused for anabolism remained unaffected. Total-tract neutral detergent fiber digestibility decreased $(-9 \%)$ with increasing low-N SF intake, indicating reduced rumen fermentation. Increasing the $\mathrm{N}$ content of $\mathrm{SF}$ at equal total $\mathrm{N}$ intake resulted in decreased urea production, excretion, and return to ornithine cycle, and increased protein retention by $17 \%$. This increase was likely related to an effect of energy availability on protein retention due to an increase in total-tract neutral detergent fiber digestion $(>10 \%)$ and due to an increased energy supply via the MR. In conclusion, increasing low-N SF intake at the expense
\end{abstract}

Received May 10, 2014.

Accepted November 8, 2014.

${ }^{1}$ Corresponding author: Harma.Berends@nutreco.com

${ }^{2}$ Current address: Nutreco Netherlands, Veerstraat 38, 5831 JN Boxmeer, the Netherlands.

${ }^{3}$ Current address: Knowledge Centre for Agriculture, Agro Food Park 15, DK-8200, Aarhus, Denmark. of $\mathrm{N}$ intake from $\mathrm{MR}$, did not affect protein retention efficiency in calves. Increasing the $\mathrm{N}$ content of SF at equal total $\mathrm{N}$ intake decreased urea production, increased protein retention, and coincided with improved fiber degradation. Therefore, results suggest that low $\mathrm{N}$ availability in the rumen limits microbial growth and rumen fermentation in calves fed low-N SF (93 g of $\mathrm{CP} / \mathrm{kg}$ of $\mathrm{DM})$, and this effect cannot be compensated for by recycling of urea originating from MR.

Key words: urea kinetics, digestibility, concentrate, milk replacer

\section{INTRODUCTION}

Optimizing solid feed (SF) strategies for veal calves has gained interest since the European Union stipulated the provision of $\mathrm{SF}$ in addition to the traditional milk replacer diet in 1997 (97/2/EC Directive by EU Council). Increasing the dietary proportion of SF for veal calves affects gastrointestinal development (Berends et al., 2012b) and nutrient utilization (Berends et al., 2012a). In recent years, the contribution of SF in veal calf diets has been increasing rapidly. It has been shown that the contribution of SF to the N economy of calves increases with age (Berends et al., 2012a, 2014b). However, interactions between milk replacer (MR) and SF on protein utilization in calves are poorly understood. In calves fed only MR, urea recycling is of limited importance (Hayashi et al., 2006), as shown by the $80 \%$ recovery of an intravenous pulse dose of $\left[{ }^{13} \mathrm{C}\right]$ urea in 48-h urine (Gerrits et al., 2001; van den Borne et al., 2006a). When milk-fed calves were supplemented with increasing amounts of low-N SF, the marginal efficiency of $\mathrm{N}$ retention was high (76\%; Berends et al., 2012a), especially when compared with marginal efficiencies of 30 to $40 \%$ reported for calves fed only MR (van den Borne et al., 2006a). The contribution of a low-N SF to the increased $\mathrm{N}$ economy of milk-fed calves was partly explained by recycling of urea, likely from MR origin, and by an effect of an increase in absorbed energy on postabsorptive $\mathrm{N}$ efficiency (Berends et al., 2014b).

At equal $\mathrm{N}$ intake, however, it is currently not known how interactions between $\mathrm{SF}$ and $\mathrm{MR}$ affect $\mathrm{N}$ deposi- 
tion in calves. Also, the route of $\mathrm{N}$ supply ( $\mathrm{SF}$ vs. MR) may affect whole-body protein metabolism. For example, ruminal microbes may prefer $\mathrm{N}$ in the form of $\mathrm{AA}$ from SF over ammonia-N from urea recycling, because ammonia is used less efficiently for microbial protein synthesis than degradable true protein (Blake et al., 1983; Argyle and Baldwin, 1989). In addition, due to diurnal fluctuations in rumen fermentation, urea recycling may not fully complement the actual $\mathrm{N}$ deficit in the rumen at specific times of the day. Improved insight in the utilization of $\mathrm{N}$ from $\mathrm{MR}$ and $\mathrm{SF}$ is required to mitigate $\mathrm{N}$ emissions from calves into the environment and to adapt feeding strategies to large fluctuations in MR ingredient prices. Apparent $\mathrm{N}$ digestibility of SF can be rather low: $45 \%$ in calves fed exclusively $\mathrm{SF}$ (Ortigues et al., 1990), whereas apparent N digestibility of MR ranges between 92 and 95\% (van den Borne et al., 2006b; Labussière et al., 2009). In contrast, SF intake will contribute to energy supply of calves, whereas increased energy supply from lactose and fat (Gerrits et al., 1996) and timing of energy relative to protein availability (van den Borne et al., 2006b, 2007, 2012) have been shown to contribute to changes in efficiency of $\mathrm{N}$ utilization for growth in calves.

Therefore, the aim of the current study was to evaluate the effects of $\mathrm{N}$ administration (via $\mathrm{SF}$ vs. via MR) at equal total dietary $\mathrm{N}$ intake on urea recycling, $\mathrm{N}$ retention, and apparent total-tract digestibility in calves. We hypothesized that at equal total dietary $\mathrm{N}$ intake, an increased proportion of $\mathrm{N}$ intake via a high-N SF increases microbial protein production, but at the same time reduces urea recycling.

\section{MATERIALS AND METHODS}

This study was conducted at the research facilities of the VanDrie Group (Scherpenzeel, the Netherlands). Procedures complied with the Dutch Law on Experimental Animals and the ETS123 (Council of Europe 1985 and the 86/609/EEC Directive) and were approved by the Animal Care and Use Committee of Wageningen University.

\section{Animals, Experimental Design, and Housing}

Thirty Dutch Holstein-Friesian male calves were included in the experiment. Calves were gathered from commercial dairy farms at $2 \mathrm{wk}$ of age $(44 \pm 0.5 \mathrm{~kg}$ of BW), and selected based on BW, uniformity, and clinical health. Upon arrival, calves were allocated to treatments based on BW. Measurements were conducted at an average BW of $180 \pm 3.7 \mathrm{~kg}$. Measurement periods were staggered from 20 and 25 wk of age, with 6 calves
(2 of each treatment) per measurement period due to limited availability of metabolic cages and infusion apparatus. The 5 -d measurement period was preceded by a 9-d adaptation period. Animal health was checked daily. Hemoglobin concentration in blood was monitored across the experiment at $3,7,11,15,19$, and 23 wk and corrected by iron injection to comply with a minimum level of $4.5 \mathrm{mmol} / \mathrm{L}$ at $27 \mathrm{wk}$ of age.

Before the adaption and measurement period, calves were housed indoors in groups of 5 calves in pens measuring $3 \times 3 \mathrm{~m}$ equipped with wooden-slatted floors and railings, and without bedding material. Calves were exposed to daylight and to artificial light from 0500 to $2300 \mathrm{~h}$ and to darkness during the remainder of the day. During the 9-d adaptation period, calves were housed for $7 \mathrm{~d}$ in individual pens placed inside the group pen to facilitate individual feeding and monitoring, and for $2 \mathrm{~d}$ in metabolic cages $(0.79 \times 1.85 \mathrm{~m})$, equipped with wooden-slatted floors and railings. When entering the metabolic cages, calves were harnessed to allow quantitative, separate collection of feces and urine. Calves remained on the metabolic cages during the subsequent 5 -d measurement period. Cages enabled audio-visual contact between calves.

\section{Diets and Feeding}

Treatments included a low level of SF with a low N content providing $12 \%$ of total $\mathrm{N}$ intake (LPLS), a high level of SF with a low N content providing $22 \%$ of total $\mathrm{N}$ intake (LPHS), or a high level of SF with a high $\mathrm{N}$ content providing $36 \%$ of total $\mathrm{N}$ intake (HPHS). Total $\mathrm{N}$ intake of all treatments was equalized to $1.8 \mathrm{~g}$ of $\mathrm{N} \cdot \mathrm{kg}$ of $\mathrm{BW}^{-0.75} \cdot \mathrm{d}^{-1}$ by adjusting $\mathrm{N}$ intake via $\mathrm{MR}$ (Table 1). Dietary treatments LPLS and LPHS included a MR with a high $\mathrm{N}$ content, whereas HPHS included a MR with a low $\mathrm{N}$ content (Table 2). The $\mathrm{N}$ content was $13.7 \mathrm{~g}$ of N/kg of DM for the low-N SF and $22.6 \mathrm{~g}$ of $\mathrm{N} / \mathrm{kg}$ of DM for the high-N SF (Table 1), which was achieved by exchanging starch-rich sources (corn and barley) for corn gluten meal in the concentrate (Table 3 ), aiming for similar rumen degradation rates of $\mathrm{CP}$, starch, NDF, and nonstarch polysaccharides (CVB, 2007). The SF was composed of $50 \%$ concentrates, $25 \%$ corn silage, and $25 \%$ chopped wheat straw on a $\mathrm{DM}$ basis. The SF was prepared in a mixing wagon (Vliebo, Veenendaal, the Netherlands) and provided restricted to minimize feed refusals. When feed refusals exceeded $10 \%$ of total $\mathrm{N}$ intake, calves were excluded from further analyses. Provision of SF started at $10 \mathrm{~d}$ after arrival. The DMI from SF increased with equal weekly increments. From $10 \mathrm{~d}$ after arrival until $10 \mathrm{wk}$ after arrival, all pens were exposed to their assigned SF 
Table 1. Nitrogen provision from milk replacer and solid feed ${ }^{1}$ to veal calves

\begin{tabular}{|c|c|c|c|c|c|c|}
\hline Treatment $^{2}$ & $\mathrm{n}$ & \multicolumn{2}{|c|}{ Milk replacer } & \multicolumn{2}{|c|}{ Solid feed } & 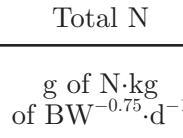 \\
\hline LPHS & 10 & 41.5 & 33.9 & 28.9 & 13.7 & 1.8 \\
\hline HPHS & 10 & 46.8 & 24.5 & 28.9 & 22.6 & 1.8 \\
\hline
\end{tabular}

${ }^{1}$ Solid feed consisted of $50 \%$ concentrates, $25 \%$ corn silage, and $25 \%$ wheat straw on a DM basis.

${ }^{2}$ LPLS = low level of solid feed with a low level of N; LPHS = high level of solid feed with a low level of N; HPHS = high level of solid feed with a high level of $\mathrm{N}$.

level, but the same $\mathrm{N}$ content $(15.0 \mathrm{~g}$ of $\mathrm{N} / \mathrm{kg}$ of $\mathrm{DM})$ was used for all pens to allow optimal rumen development as assessed in earlier studies (Suárez et al., 2007; Berends et al., 2012b). From wk 10 after arrival, calves were exposed to their final treatments. Total DMI from SF during wk 10 to 27 was targeted to reach $100 \mathrm{~kg}$ for LPLS and $260 \mathrm{~kg}$ for LPHS and HPHS (Berends et al., 2014b). Before the start of the adaptation period, the preplanned quantity of MR was slightly adjusted every 2 wk to achieve similar BW across treatments at the onset of the adaptation period.

Table 2. Ingredient and analyzed nutrient composition of the milk replacers $(\mathrm{MR})$

\begin{tabular}{|c|c|c|}
\hline Item & $\begin{array}{c}\text { Low-N } \\
\text { MR }\end{array}$ & $\begin{array}{c}\text { High-N } \\
\text { MR }\end{array}$ \\
\hline \multicolumn{3}{|l|}{ Ingredient composition, $\mathrm{g} / \mathrm{kg}$} \\
\hline Fat-enriched whey ${ }^{1}$ & 410.9 & 394.0 \\
\hline Whey protein concentrate & 0.0 & 193.9 \\
\hline Whey & 354.1 & 143.3 \\
\hline Delactosed whey & 118.2 & 135.0 \\
\hline Soy protein isolate & 25.8 & 37.7 \\
\hline Soy protein concentrate & 15.0 & 25.0 \\
\hline Acidified whey $^{2}$ & 20.0 & 20.0 \\
\hline Pregelatinized wheat starch & 24.0 & 20.0 \\
\hline Vitamin and mineral premix ${ }^{3}$ & 10.0 & 10.0 \\
\hline Calcium formate & 10.4 & 9.8 \\
\hline L-Lysine $\cdot \mathrm{HCl}$ & 4.8 & 5.2 \\
\hline DL-Methionine & 2.0 & 2.7 \\
\hline Citric acid & 2.0 & 2.0 \\
\hline Mono ammonium phosphate & 2.0 & 1.4 \\
\hline L-Threonine & 1.0 & 0.2 \\
\hline \multicolumn{3}{|c|}{ Nutrient composition, ${ }^{4} \mathrm{~g} / \mathrm{kg}$ of DM } \\
\hline $\mathrm{DM}, \mathrm{g} / \mathrm{kg}$ product & 971.1 & 969.7 \\
\hline $\mathrm{CP}, \mathrm{N} \times 6.25$ & 158.6 & 203.0 \\
\hline Crude fat & 211.7 & 206.4 \\
\hline Starch & 26.1 & 21.0 \\
\hline
\end{tabular}

${ }^{1}$ Fat-enriched whey contained $50 \%$ fat from palm oil and coconut oil $(80 / 20, \% \mathrm{wt} / \mathrm{wt})$.

${ }^{2}$ Acidified with lactate, provided $5.9 \mathrm{~g}$ of lactate per $\mathrm{kg}$ of the experimental diet.

${ }^{3}$ Provided per kilogram of the experimental diet: $16.6 \mathrm{~g}$ of K, $15.5 \mathrm{~g}$ of $\mathrm{Cl}, 8.3 \mathrm{~g}$ of $\mathrm{Fe}, 6.1 \mathrm{~g}$ of P, $5.9 \mathrm{~g}$ of $\mathrm{Cu}, 5.7 \mathrm{~g}$ of $\mathrm{Na}, 1.3 \mathrm{~g}$ of $\mathrm{Mg}, 25,000$ IU of vitamin A, 4,000 IU of vitamin $\mathrm{D}_{3}$, and $100 \mathrm{IU}$ of vitamin $\mathrm{E}$.

${ }^{4}$ Expressed in grams per kilogram of DM unless specified otherwise.
The MR was reconstituted with water and the concentration increased gradually from 125 to $188 \mathrm{~g} / \mathrm{L}$. The MR was supplied in buckets at approximately $40^{\circ} \mathrm{C}$ and provided twice daily in equal-sized meals at 0600 and $1600 \mathrm{~h}$. Until the adaptation period, SF was provided as a TMR in a long feed trough in front of the pen directly after the morning meal; refusals were collected once daily, before the morning MR meal, and weighed. During the adaptation and measurement period, SF was supplied individually twice daily in an individual feed trough directly after the MR feeding; refusals were collected before each MR meal and weighed. Calves had ad libitum access to water during the experiment via drinking nipples.

\section{Isotope Infusion}

On the first day of the measurement period, calves were prepared with central venous catheters (Careflow, Becton Dickinson, Alphen aan den Rijn, the Netherlands) for infusion. A 24-h continuous infusion of

Table 3. Analyzed nutrient composition of low- and high-N concentrate, corn silage, and wheat straw

\begin{tabular}{|c|c|c|c|c|}
\hline \multirow[b]{2}{*}{ Nutrient $^{1}$} & \multicolumn{2}{|c|}{ Concentrate $^{2}$} & \multirow{2}{*}{$\begin{array}{c}\text { Corn } \\
\text { silage }\end{array}$} & \multirow{2}{*}{$\begin{array}{l}\text { Wheat } \\
\text { straw }\end{array}$} \\
\hline & Low N & High N & & \\
\hline $\mathrm{DM}, \mathrm{g} / \mathrm{kg}$ of product & 899 & 908 & 284 & 927 \\
\hline $\mathrm{CP}, \mathrm{N} \times 6.25$ & 138 & 246 & 67 & 29 \\
\hline Crude fat & 66 & 69 & 29 & 9 \\
\hline Starch & 424 & 332 & 322 & 9 \\
\hline $\mathrm{NDF}$ & 116 & 116 & 427 & 813 \\
\hline
\end{tabular}

${ }^{1}$ Expressed in grams per kilogram of DM unless specified otherwise.

${ }^{2}$ Concentrate composition for low- $\mathrm{N}$ concentrate: $42.0 \%$ corn, $21.0 \%$ lupins, $23.6 \%$ barley, $5.0 \%$ carob meal, $2.5 \%$ coconut oil, $6 \%$ premix (lactose carrier, provided per kilogram of concentrate: vitamin A 4,000 IU; vitamin D: $500 \mathrm{IU}$; vitamin E: $100 \mathrm{IU}$; zinc: $25 \mathrm{mg}$; manganese: $20 \mathrm{mg}$; iodine: $0.8 \mathrm{mg}$; selenium: $0.15 \mathrm{mg}$; copper: $15 \mathrm{mg}$; cobalt: $0.1 \mathrm{mg}, 1.13 \mathrm{~g}$ of magnesium (magnesium sulfate), $3.0 \mathrm{~g}$ of sodium $(\mathrm{NaCl}), 8.6 \mathrm{~g}$ of calcium $\left(\mathrm{CaCO}_{3}\right), 3.9 \mathrm{~g}$ of $\mathrm{K}\left(\mathrm{KH}_{2} \mathrm{PO}_{4}\right)$. Concentrate composition for high- $\mathrm{N}$ concentrate: $31.8 \%$ corn, $21.0 \%$ lupins, $17.9 \%$ barley, $15.8 \%$ corn gluten meal, $5.0 \%$ carob meal, $2.5 \%$ coconut oil, $6 \%$ premix (identical to premix in low- $\mathrm{N}$ concentrate). 
doubly ${ }^{15} \mathrm{~N}$ labeled urea $\left(\left[{ }^{15} \mathrm{~N}^{15} \mathrm{~N}\right]\right.$ urea, $>99.0$ atom\%, ISOTEC, Miamisburg, $\mathrm{OH}$ ) prepared in sterile saline $(0.15 \mathrm{M} \mathrm{NaCl})$ was conducted. The continuous infusion of $0.039 \mathrm{~mL} / \mathrm{min}(2.09 \mathrm{mmol} / \mathrm{d})$ was preceded by a priming dose of $1.05 \mathrm{mmol}$ to enrich the body urea pool to approximately $0.15 \mathrm{~mol}$ percent excess.

\section{Measurements}

The $\mathrm{N}$ balance was calculated from quantitative measurements of MR and SF intake, and feces and urine excretion for $120 \mathrm{~h}$. Urine was collected quantitatively in buckets and acidified to $\mathrm{pH}<2$ with sulfuric acid to prevent microbial activity and ammonia volatilization. Feces were collected quantitatively in plastic bags that were attached to calves and renewed 3 times per day. During each measurement period, MR and SF components were sampled. Each calf was weighed before and after the measurement period. For quantification of urea recycling, urine samples were taken before the infusion (background samples) and a pooled sample was taken for the 72-h period after the initiation of the infusion. The same was done for feces.

\section{Analyses}

Urinary urea was isolated using a cation exchange resin (AG 50WX8, 200 to 400 mesh hydrogen form, Sigma-Aldrich, St. Louis, MO) and diluted to a final concentration of $1.65 \mathrm{mmol} / \mathrm{L}$. The eluates were analyzed according to Sarraseca et al. (1998) with some modifications leading to monomolecular degradation of urea into $\mathrm{N}_{2}$ as described by Berends et al. (2014a). Urinary urea was determined by an enzymatic colorimetric Berthelot method (Human, Wiesbaden, Germany). Samples of MR, concentrates, corn silage, and straw were collected weekly. All feed components, except for corn silage, were pooled for the 5 consecutive measurement periods. Feed components (MR, corn silage, concentrates, straw) were analyzed for DM, N, starch, NDF (except for MR), and crude fat content. For determination of DM content, corn silage and concentrate samples were freeze-dried. Concentrates, straw, and corn silage samples were ground to pass a 1-mm screen. Dry matter content was determined by drying to a constant weight according to ISO Standard 6496 (ISO, 1998). Kjeldahl N content was determined according to ISO 5983 (ISO, 1997). Crude fat content was determined after acid hydrolysis according to ISO 6496 (ISO, 1999). The NDF content was analyzed according to Van Soest et al. (1991). Starch content was determined enzymatically as described by Rijnen et al. (2001).

\section{Calculations}

The multiple-entry urea kinetic model of Zuur et al. (2000) was used to calculate urea-N kinetics. The model yields estimates of urea entry rate (UER) and the fate of this to urine (UUE), the gut (GER), and resolution of the latter as recycled to the ornithine cycle (ROC), excreted in feces (UFE), or used for microbial anabolism (UUA).

\section{Statistical Analysis}

For the $\mathrm{N}$ balance, the data set included 26 successful observations: 10 LPLS calves, 8 LPHS calves, and 8 HPHS calves, respectively. Calves were excluded because of clinical sickness (1 calf), or feed refusals exceeding $10 \%$ of targeted total $\mathrm{N}$ intake (3 calves; 2 LPHS calves and 1 LPLS calf). For urea kinetics, 1 extra observation (1 calf LPHS) was excluded from the data set because of a missing sample. Dependent variables were analyzed by mixed model analysis (PROC MIXED in SAS 9.20 by SAS Institute Inc., Cary, NC), with calf as the experimental unit, including pen before the adaption period as random effect, treatment, and measurement period as fixed effects, and their interaction as fixed effects. The random effect of pen and the interaction between measurement period and treatment were not significant and therefore excluded from the model. Pairwise differences, with Tukey adjustments for multiple comparisons, were determined when the effect of treatment appeared significant. Model residuals were checked for normal distribution. Results are presented as least squares means and their SEM. Differences were considered significant at $P<0.05$.

\section{RESULTS}

Due to SF and MR refusals and slight differences between estimated and analyzed $\mathrm{N}$ contents of $\mathrm{SF}$ and MR, the targeted total $\mathrm{N}$ intake of $1.80 \mathrm{~g}$ of $\mathrm{N} \cdot \mathrm{kg}$ of $\mathrm{BW}^{-0.75} \cdot \mathrm{d}^{-1}$ was not fully achieved for LPLS and LPHS (Table 4). Therefore, the realized proportion of total N intake originating from SF was $12 \%$ for LPLS, $23 \%$ for LPHS, and $34 \%$ for HPHS.

\section{Effect of Low-N SF Level}

Fecal $\mathrm{N}$ excretion was greater for LPHS than for LPLS $(+31 \%)$, and accompanied by a reduction of $8 \%$ in digestible $\mathrm{N}$ intake. However, $\mathrm{N}$ retention, $\mathrm{UER}$, and UUA did not differ between LPLS and LPHS (Table $5)$, although ROC and UFE were greater $(P<0.05)$ for LPHS. Apparent total-tract digestibilities of starch 


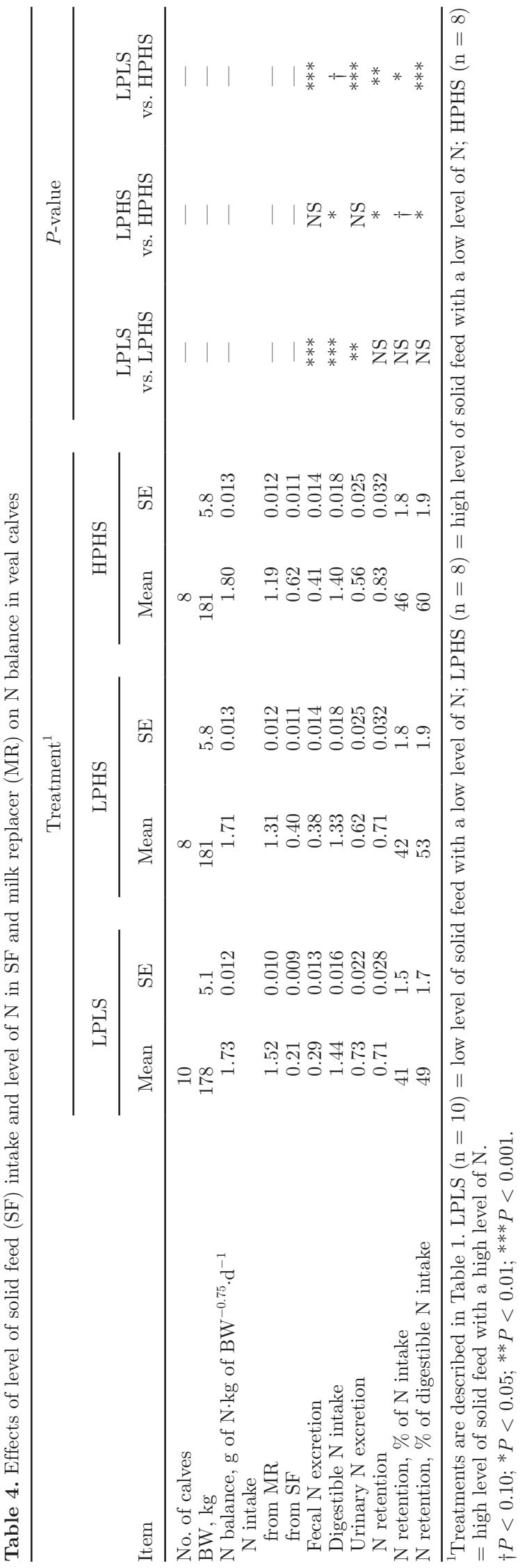

$(+1 \%), \mathrm{CP}(+5 \%)$, and NDF $(+9 \%)$ were greater for LPLS than for LPHS (Table 6).

\section{Effect of N Content of SF}

Due to $\mathrm{SF}$ and $\mathrm{MR}$ refusals, total $\mathrm{N}$ intake was slightly lower in LPHS calves than in HPHS calves. As a result, digestible $\mathrm{N}$ intake $(P<0.05)$ was lower for LPHS than for HPHS (Table 4$)$. The UER $(+25 \%)$, UUE $(+29 \%)$, ROC $(+78 \%)$, and UFE $(+50 \%)$ were greater $(P<0.05)$ for LPHS than for HPHS. However, UUA did not differ. Nitrogen retention was $17 \%$ greater $(P<0.05)$ for HPHS than for LPHS. Apparent total-tract digestibility of crude fat $(+2 \%)$ tended to be greater $(P<0.10)$ for LPHS than for HPHS, whereas apparent total-tract digestibilities of starch $(+1 \%)$ and NDF $(+11 \%)$ were greater for HPHS than for LPHS (Table 6).

\section{Effect of SF Level and N Content of SF}

Fecal N excretion was $41 \%$ greater $(P<0.001)$ for HPHS than for LPLS, and digestible $\mathrm{N}$ intake tended to be greater $(P<0.10)$ for LPLS. Nitrogen retention was $17 \%$ greater $(P<0.01)$ in HPHS calves, and urinary $\mathrm{N}$ excretion was $30 \%$ greater $(P<0.001)$ in LPLS calves. Also, as a percentage of intake, $\mathrm{N}$ retention was greater $(P<0.05)$ for HPHS calves than for LPLS calves. In accordance with the increase in $\mathrm{N}$ retention, UER was lower $(P<0.05)$ for HPHS calves than for LPLS calves. Digestibility of crude fat tended to be greater $(P<$ $0.10)$ and digestibility of $\mathrm{CP}$ was greater $(P<0.001)$ in LPLS than in HPHS calves.

\section{DISCUSSION}

When fed exclusively on MR, the marginal efficiency of protein utilization for growth typically is 30 to $40 \%$ in heavy calves $(>100 \mathrm{~kg}$ of BW) and decreases with age (van den Borne et al., 2006a). When combining MR and low-N SF in calves, urea originating from deamination of AA from MR can contribute to protein gain through urea recycling. As a consequence, incremental amounts of $\mathrm{N}$ from low-N SF were retained with an efficiency of $76 \%$ (Berends et al., 2012a). The aim of the current study was to evaluate the effects of protein provision via $\mathrm{SF}$ or $\mathrm{MR}$, on urea recycling, whole body $\mathrm{N}$ retention, and apparent total-tract digestibility in calves.

\section{Increasing Low-N SF Provision}

Results showed that, within the range applied in the current study, $1 \mathrm{~g}$ of $\mathrm{N}$ from SF was used as efficiently 
as $1 \mathrm{~g}$ of $\mathrm{N}$ from MR for $\mathrm{N}$ deposition in calves at equal total $\mathrm{N}$ intake (e.g., in the comparison between LPLS vs. LPHS). This equal utilization of $\mathrm{N}$ from $\mathrm{SF}$ and $\mathrm{MR}$ is rather surprising because of the high digestibility and quality of milk protein. Potentially, differences in nutrient synchrony affect $\mathrm{N}$ utilization from AA from SF compared with MR. Nutrient synchronization in general (van den Borne et al., 2006b) and AA synchronization specifically (van den Borne et al., 2012) influence the utilization of dietary protein in calves. Kinetics of digestion of protein from SF likely differ from MR. Portal appearance of AA originating from SF protein is likely to be more gradual than the rather peak-wise portal appearance of AA originating from MR. This is supported by heat production profiles in calves fed incremental amounts of SF in combination with a constant amount of MR (Berends et al., 2012a).

Despite identical $\mathrm{N}$ retention, digestible $\mathrm{N}$ intake was greater $\left(+0.11 \mathrm{~g}\right.$ of $\mathrm{N} \cdot \mathrm{kg}$ of $\left.\mathrm{BW}^{-0.75} \cdot \mathrm{d}^{-1}\right)$ for LPLS than for LPHS, and accompanied by an increased GER $\left(+0.08 \mathrm{~g}\right.$ of $\mathrm{N} \cdot \mathrm{kg}$ of $\left.\mathrm{BW}^{-0.75} \cdot \mathrm{d}^{-1}\right)$, ROC $(+0.08$ $\mathrm{g}$ of $\mathrm{N} \cdot \mathrm{kg}$ of $\left.\mathrm{BW}^{-0.75} \cdot \mathrm{d}^{-1}\right)$, and UFE $(+0.02 \mathrm{~g}$ of $\mathrm{N} \cdot \mathrm{kg}$ of $\left.\mathrm{BW}^{-0.75} \cdot \mathrm{d}^{-1}\right)$. However, the increased digestible $\mathrm{N}$ intake and urea recycling were not reflected by an increase in UUA.

In general, the apparent digestibility of a SF decreases with increasing SF intake (NRC, 2001). Therefore, the greater starch and NDF digestibility in LPLS calves could be related to a lower SF intake or to a numerical increase in urea recycling (from deamination of AA originating from MR) to complement a potential $\mathrm{N}$ deficit for microbial fermentation in the rumen. In dairy cows, rumen degradation of carbohydrates is impaired when the $\mathrm{N}$ content of SF does not exceed $16 \%$ (Oldham, 1984). In the current study, the increased level of low-N SF and the reduced $\mathrm{N}$ intake from MR may have limited rumen fermentation in LPHS calves.

\section{Low-N Versus High-N SF}

Increasing $\mathrm{N}$ supply through $\mathrm{SF}$ increased $\mathrm{N}$ retention by $17 \%$. Due to feed refusals, $\mathrm{N}$ intake was slightly greater in HPHS calves. When $\mathrm{N}$ retention was expressed as a percentage of $\mathrm{N}$ intake, however, $\mathrm{N}$ retention was still $13 \%$ greater for HPHS calves than for LPHS calves. The efficiency of $\mathrm{N}$ retention is known to be quadratically related to $\mathrm{N}$ intake in milk-fed and SFfed calves, reaching a maximum at approximately 1.8 $\mathrm{g} \cdot \mathrm{kg}$ of $\mathrm{BW}^{-0.75} \cdot \mathrm{d}^{-1}$ (Zanton and Heinrichs, 2008), which is close to the $\mathrm{N}$ retention found in the current study. Although digestible $\mathrm{N}$ intake was $5 \%$ greater in HPHS calves (Table 4), UER was $25 \%$ greater for LPHS than for HPHS calves (Table 5). Postabsorptive utilization of $\mathrm{N}$ for growth therefore increased substantially when 
Table 6. Effects of $\mathrm{N}$ level of solid feed and milk replacer, and solid feed intake on apparent total-tract digestibility of crude fat, starch, CP, and NDF in veal calves

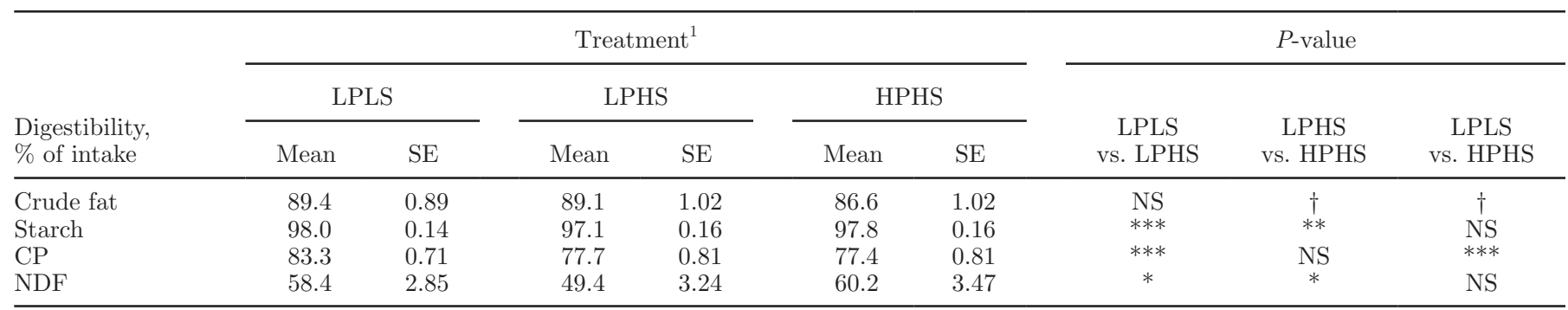

${ }^{1}$ Treatments are described in Table 1. LPLS $(\mathrm{n}=10)=$ low level of solid feed with a low level of N; LPHS $(\mathrm{n}=8)=$ high level of solid feed with a low level of N; HPHS $(\mathrm{n}=8)=$ high level of solid feed with a high level of $\mathrm{N}$.

$\dagger P<0.10 ;{ }^{*} P<0.05 ; * * P<0.01 ; * * * P<0.001$

$\mathrm{N}$ content of the $\mathrm{SF}$ increased at equal total $\mathrm{N}$ intake, which may be explained by various mechanisms.

First, UUA remained unaffected across treatments. In the current study, 60 to $76 \%$ of GER was converted to UUA, which is in the upper range of previously reported values in cattle and sheep as reviewed by Lapierre and Lobley (2001). The observed increase in NDF digestibility in HPHS calves has been shown previously in dairy cattle that increasing dietary $\mathrm{CP}$ content increased ruminal digestion (Doreau et al., 1990; Belanche et al., 2012). Finally, rumen microbes may prefer $\mathrm{N}$ from AA over $\mathrm{N}$ from urea (Blake et al., 1983; Argyle and Baldwin, 1989) and the supply of dietary AA to the rumen was greater for HPHS calves.

Second, digestible energy (DE) intake differed between treatments, which is known to affect $\mathrm{N}$ deposition in calves independently of $\mathrm{N}$ intake (Ortigues et al., 1990; Gerrits et al., 1996; Schroeder et al., 2006). The DE intake could be estimated from gross energy values (CVB, 2007; Berends et al., 2012a) and assumed digestibilities of gross energy from MR (van den Borne et al., 2006b; Labussière et al., 2009) and SF (Berends et al., 2012a): $1,027,1,117$, and $1,228 \mathrm{~kJ} \cdot \mathrm{kg}$ of $\mathrm{BW}^{-0.75} \cdot \mathrm{d}^{-1}$ for LPLS, LPHS, and HPHS, respectively. The difference in the estimated DE intake between LPHS and LPLS was $100 \mathrm{~kJ} \cdot \mathrm{kg}$ of $\mathrm{BW}^{-0.75} \cdot \mathrm{d}^{-1}$; the difference between HPHS and LPHS was also $100 \mathrm{~kJ} \cdot \mathrm{kg}$ of $\mathrm{BW}^{-0.75} \cdot \mathrm{d}^{-1}$. The efficiency of protein utilization may have increased as a result of an increased DE intake. Notably, the difference in N efficiency between HPHS and LPHS was larger than the difference between LPHS and LPLS. However, the true difference in DE intake between HPHS and LPHS may have been larger than the calculated difference of $100 \mathrm{~kJ} \cdot \mathrm{kg}$ of $\mathrm{BW}^{-0.75} \cdot \mathrm{d}^{-1}$, due to the reported increase in NDF digestion. When assuming the effect of protein-free energy intake on $\mathrm{N}$ retention to be $33 \mathrm{~kJ}$ of DE. $\mathrm{kg}$ of $\mathrm{BW}^{-0.75}$.g of $\mathrm{N}^{-1}$ (Gerrits et al., 1996), a substantial portion of the observed increase in $\mathrm{N}$ retention may be explained by an increase in $\mathrm{DE}$ intake.

\section{CONCLUSIONS}

Results of the current study show that increasing low$\mathrm{N}$ SF intake at the expense of $\mathrm{N}$ intake from MR does not alter whole body $\mathrm{N}$ retention or UUA in calves. We hypothesized that at equal $\mathrm{N}$ intake, an increased proportion of $\mathrm{N}$ intake via a high-N SF would increase microbial protein production, but that urea recycling would be reduced. Increasing the $\mathrm{N}$ content of $\mathrm{SF}$ at equal total $\mathrm{N}$ and equal $\mathrm{SF}$ intake increased $\mathrm{N}$ retention by $17 \%$ in calves. Digestibility of NDF increased by more than $10 \%$, which may be explained by the preferential use of protein- $\mathrm{N}$ over urea- $\mathrm{N}$ for microbial protein synthesis in the rumen. Data indicate that a greater energy supply with a greater $\mathrm{N}$ content of SF contributed to the observed N retention. Results suggest that rumen fermentation, and thus fiber degradation of a low-N SF (93 g of CP $/ \mathrm{kg}$ of DM), is hampered by the low protein availability. Recycling of urea cannot compensate for this effect.

\section{ACKNOWLEDGMENTS}

The authors thank the Division for Earth and Life Sciences (ALW) of the Netherlands Organisation for Scientific Research (The Hague, the Netherlands), and the Product Board Animal Feed (The Hague, the Netherlands) for financially supporting this research. Klaas Boeder, Bart Evers, Ewart van Voorst (VanDrie Group, Scherpenzeel, the Netherlands), Joswita van de Velde, Teun Keizer, Sven Alferink, Tamme Zandstra, Michel Breuer (Animal Nutrition Group, Wageningen University), André Jansen, Bert Beukers (Department of Animal Sciences, Wageningen University, the Netherlands), and Birgit Løth and Anne Krustrup 
(Department of Animal Health and Bioscience, Aarhus University) are gratefully acknowledged for their skilled technical assistance.

\section{REFERENCES}

Argyle, J., and R. Baldwin. 1989. Effects of amino acids and peptides on rumen microbial growth yields. J. Dairy Sci. 72:2017-2027.

Belanche, A., M. Doreau, J. E. Edwards, J. M. Moorby, E. Pinloche, and C. J. Newbold. 2012. Shifts in the rumen microbiota due to the type of carbohydrate and level of protein ingested by dairy cattle are associated with changes in rumen fermentation. J. Nutr. 142:1684-1692.

Berends, H., J. J. G. C. van den Borne, S. J. J. Alferink, C. G. van Reenen, E. A. M. Bokkers, and W. J. J. Gerrits. 2012a. Low-protein solid feed improves the utilization of milk replacer for protein gain in veal calves. J. Dairy Sci. 95:6654-6664.

Berends, H., J. J. G. C. van den Borne, H. Mollenhorst, C. G. van Reenen, E. A. M. Bokkers, and W. J. J. Gerrits. 2014b. Utilization of roughages and concentrates relative to that of milk replacer increases strongly with age in veal calves. J. Dairy Sci. 97:6475-6484

Berends, H., J. J. G. C. van den Borne, B. A. Røjen, J. van Baal, and W. J. J. Gerrits. 2014a. Urea recycling contributes to nitrogen retention in calves fed milk replacer and low-protein solid feed. J. Nutr. 10.3945/jn.114.191353.

Berends, H., C. G. van Reenen, N. Stockhofe-Zurwieden, and W. J. J. Gerrits. 2012b. Effects of early rumen development and solid feed composition on growth performance and abomasal health in veal calves. J. Dairy Sci. 95:3190-3199.

Blake, J., D. Salter, and R. Smith. 1983. Incorporation of nitrogen into rumen bacterial fractions of steers given protein-and ureacontaining diets. Ammonia assimilation into intracellular bacterial amino acids. Br. J. Nutr. 50:769-782.

CVB. 2007. Chemical compositions and nutritional values of feed ingredients. Centraal Veevoeder Bureau, Productschap Diervoeder, Den Haag, the Netherlands.

Doreau, M., A. Delacroix, J. Jouany, C. Durier, and B. Rémond. 1990. The influence of physiological state and dietary nitrogen supply on digestion in the dairy cow. J. Anim. Sci. 68:3853-3860.

Gerrits, W. J. J., G. M. Beelen, J. Dijkstra, and J. M. A. J. Verdonk. 2001. Ammonia infusion and starch fermentation in preruminant calves (150-180 kg). Internal report No. V99.001. ID TNO Anmial Nutrition (in Dutch), Wageningen, the Netherlands.

Gerrits, W. J. J., G. H. Tolman, J. W. Schrama, S. Tamminga, M. W. Bosch, and M. W. A. Verstegen. 1996. Effect of protein and protein-free energy intake on protein and fat deposition rates in preruminant calves of 80 to $240 \mathrm{~kg}$ live weight. J. Anim. Sci. $74: 2129-2139$

Hayashi, H., M. Kawai, I. Nonaka, F. Terada, K. Katoh, and Y. Obara. 2006. Developmental changes in the kinetics of glucose and urea in Holstein calves. J. Dairy Sci. 89:1654-1661.

ISO. 1997. Animal feeding stuffs - Determination of nitrogen content and calculation of crude protein content. ISO 5983. Int. Organ. Stand., Geneva, Switzerland.
ISO. 1998. Animal feeding stuffs - Determination of moisture and other volatile matter content. ISO 6496. Int. Organ. Stand., Geneva, Switzerland.

ISO. 1999. Animal feeding stuffs-Determination of fat content. ISO 6492. Int. Organ. Stand., Geneva, Switzerland.

Labussière, E., S. Dubois, J. van Milgen, G. Bertrand, and J. Noblet. 2009. Effect of solid feed on energy and protein utilization in milkfed veal calves. J. Anim. Sci. 87:1106-1119.

Lapierre, H., and G. Lobley. 2001. Nitrogen recycling in the ruminant: A review. J. Dairy Sci. 84:E223-E36.

NRC. 2001. Nutrient Requirements of Dairy Cattle. 7th rev. ed. Natl. Acad. Sci., Washington, DC.

Oldham, J. 1984. Protein-energy interrelationships in dairy cows. J. Dairy Sci. 67:1090-1114.

Ortigues, I., T. Smith, M. Gill, S. B. Cammell, and N. W. Yarrow. 1990. The effect of fishmeal supplementation of a straw-based diet on growth and calorimetric efficiency of growth in heifers. Br. J. Nutr. 64:639-651.

Rijnen, M., M. Verstegen, M. Heetkamp, J. Haaksma, and J. Schrama. 2001. Effects of dietary fermentable carbohydrates on energy metabolism in group-housed sows. J. Anim. Sci. 79:148-154.

Sarraseca, A., E. Milne, M. Metcalf, and G. Lobley. 1998. Urea recycling in sheep: effects of intake. Br. J. Nutr. 79:79-88.

Schroeder, G., E. Titgemeyer, M. Awawdeh, J. Smith, and D. Gnad. 2006. Effects of energy source on methionine utilization by growing steers. J. Anim. Sci. 84:1505-1511.

Suárez, B. J., C. G. Van Reenen, N. Stockhofe, J. Dijkstra, and W. J. J. Gerrits. 2007. Effect of roughage source and roughage to concentrate ratio on animal performance and rumen development in veal calves. J. Dairy Sci. 90:2390-2403.

van den Borne, J., S. J. Alferink, M. J. Heetkamp, A. A. Jacobs, M. W. Verstegen, and W. J. Gerrits. 2012. Asynchronous supply of indispensable amino acids reduces protein deposition in milk-fed calves. J. Nutr. 142:2075-2082.

van den Borne, J., J. F. Hocquette, M. W. A. Verstegen, and W. W. J. Gerrits. 2007. Whole body and muscle energy metabolism in preruminant calves: Effects of nutrient synchrony and physical activity. Br. J. Nutr. 97:667-675.

van den Borne, J., J. Verdonk, J. W. Schrama, and W. J. J. Gerrits. 2006a. Reviewing the low efficiency of protein utilization in heavy preruminant calves - A reductionist approach. Reprod. Nutr. Dev. $46: 121-137$.

van den Borne, J., M. W. A. Verstegen, S. J. J. Alferink, R. M. M. Giebels, and W. J. J. Gerrits. 2006b. Effects of feeding frequency and feeding level on nutrient utilization in heavy preruminant calves. J. Dairy Sci. 89:3578-3586.

Van Soest, P. J., J. Robertson, and B. Lewis. 1991. Methods for dietary fiber, neutral detergent fiber, and nonstarch polysaccharides in relation to animal nutrition. J. Dairy Sci. 74:3583-3597.

Zanton, G., and A. Heinrichs. 2008. Analysis of nitrogen utilization and excretion in growing dairy cattle. J. Dairy Sci. 91:1519-1533.

Zuur, G., K. Russell, and G. Lobley. 2000. Multiple-entry urea kinetic model: Effects of incomplete data collection. J. P. McNamara, J. France, and D. Beever, ed. Modelling nutrient utilization in farm animals. CABI Publishing, Wallingford, UK. 2000:145-161. 